\title{
KAJIAN PEROLEHAN KOMPETENSI KEAHLIAN BUSANA BUTIK SISWA SMK: STUDI KASUS PRAKERIN DI INDUSTRI PASANGAN
}

\author{
Sri Handayani \\ Fakultas Teknik Universitas Negeri Yogyakarta \\ anyzt90@yahoo.co.id, \\ Sri Wening \\ Fakultas Teknik Universitas Negeri Yogyakarta \\ riwening@yahoo.com
}

\begin{abstract}
Abstrak
Penelitian ini bertujuan untuk mengetahui perolehan kompetensi siswa di setiap DUDI, khususnya busana butik yang memiliki pola pembimbingan berbeda. Penelitian ini menggunakan jenis penelitian studi kasus pendekatan kualitatif. Teknik penentuan Informan menggunakan snowball sampling yaitu instruktur industri, pembimbing, dan siswa SMK N 1 Pengasih yang sedang prakerin. Pengumpulan data menggunakan wawancara, observasi dan dokumentasi. Teknik analisis data mengacu pada analisis model interaktif Miles \& Huberman, meliputi pengumpulan data, data condensation, penyajian data, dan deskripsi serta verifikasi kesimpulan. Hasil penelitian adalah (1) praktik yang dijalani siswa sudah relevan dengan kurikulum yang tercantum di sekolah; (2) perolehan kompetensi pada aspek kognitif siswa memperoleh pengetahuan tentang prosedur pembuatan busana butik, pada aspek afektif terbentuk sikap budaya kerja, dan pada aspek psikomotor mampu menyelesaikan pekerjaan busana butik; (3) cara siswa memperoleh kompetensi dengan melakukan: (a) komunikasi; (b) teknik belajar (c) metode kerja praktis; (d) pekerjaan secara mandiri; (e) tindakan dengan tanggung jawab; (f) etos kerja; $(g)$ pengorganisasian dan implementasi kerja dengan baik; $(h)$ bekerja sesuai kepercayaan instruktur industri; (i) pengembangan diri; dan (j) penerapan kompetensi dari sekolah; (4) pencapaian kompetensi siswa yang prakerin di Goet Poespo dan Puspa Rini berada pada level Pemula (novices) sedangkan di L'Mar butik pada level spesialist.
\end{abstract}

Kata kunci: perolehan kompetensi, prakerin, busana butik.

\section{A STUDY ON COMPETENCE EXPERTISE ACHIEVEMENT OF BOUTIQUE CLOTHING FOR VOCATIONAL STUDENTS: A CASE STUDYOF INDUSTRY WORK PRACTICE IN PARTNER INDUSTRY}

\begin{abstract}
This research aimed to determine the competence of the students in each "DUDI", especially in fashion boutiques that had different patterns of coaching. The research used a qualitative case study approach. A snowball sampling technique was used to select informants which consisted of the industrial mentors, the school mentor, and students. who were on industry work practice. The data were collected through interviews, and documentation. The data analysis technique refered to the analysis of Miles \& Huberman interactive model, including data collection, data condensation, data display, and drawing and verifying conclusions. The result were (1) the practice done by the students was relevant with the curriculum written in the school; (2) in the competence achievement of cognitive aspect the student got the knowledge of boutique dressmaking procedures, in affective aspect, there was a development of work culture attitudes and in the psychomotor aspects, they were able to finish boutique clothes work; (3) the ways of achieving the competence were through: (a) communication, (b) learning techniques, (c)methods, (d) working independently, (e) acting with responsibility, $(f)$ adhering to work ethics, $(g)$ good organization and implementation, ( $h$ ) working in line with the trust given by the industry instructor, (i)self-development, (j) applying the school competencies; (4) the competence achievement of the students who did industry work practice in Goet Poespo and Puspa Rini was at the novice level, while the ones in L'Mar boutique were at the specialist level.
\end{abstract}

Keywords: competence acquisition, industry work practice, clothing boutiques 


\section{PENDAHULUAN}

Sumber Daya Manusia (SDM) saat ini dituntut agar senantiasa lebih aktif dan kompeten. Hal tersebut dapat dilihat dari kebutuhan manusia yang semakin meningkat. Salah satu upaya manusia agar menjadi manusia dengan kualitas memadai yaitu melalui pendidikan. Pendidikan sampai saat ini dianggap sebagai unsur utama dalam pengembangan SDM dan berkorelasi terhadap pertumbuhan ekonomi. Sekolah Menengah Kejuruan (SM$\mathrm{K})$ adalah salah satu bentuk satuan pendidikan formal yang menyelenggarakan pendidikan kejuruan pada jenjang pendidikan menengah.

SMK bertujuan menyiapkan lulusan yang siap kerja, terampil, mempunyai daya saing yang tinggi dan menjadi warga negara yang kreatif untuk mengembangkan sikap professional dalam pekerjaan yang mengacu pada tuntutan pasar kerja dan industri di berbagai bidang keahlian. Hal ini dapat dijelaskan bahwa SMK sebagai lembaga pendidikan dapat dipandang sebagai suatu sistem yang terdiri dari input, proses dan output. Oleh karena itu, untuk menjadikan input menjadi suatu output yang baik ataupun berkualitas, maka diperlukan proses yang baik pula

Siswa SMK merupakan input. Oleh karena itu, supaya input yang berdaya guna dan berdaya saing serta memiliki sikap, perilaku, wawasan, kemampuan, keahlian serta keterampilan yang sesuai kebutuhan dunia kerja, maka SMK harus dilengkapi dengan berbagai fasilitas sarana prasarana, kurikulum, dan kompetensi yang utuh. Pencapaian kompetensi lulusan SMK yang sesuai dengan tuntutan pasar kerja dan industri di berbagai bidang keahlian diharapkan dapat diserap oleh dunia industri sesuai dengan bidangnya masingmasing. Namun, kenyataanya masih banyak lulusan SMK yang belum diserap oleh DUDI (Dunia Usaha/ Dunia Industri). Salah satu faktor yang mempengaruhi masih rendahnya keterserapan lulusan SMK oleh DUDI yaitu kompetensi yang dimiliki lulusan tidak sesuai dengan tuntutan dunia kerja.

Ketidaksesuaian kompetensi yang dimaksud adanya kompetensi yang tidak utuh dikarenakan ketidaktercapaian kompetensi yang diperoleh siswa. Mencapai kompetensi yang utuh tidak dapat secara instan akan tetapi diperlukan suatu proses. Proses yang dimaksud adalah perolehan kompetensi yang di- dalamnya siswa dituntut untuk memiliki keterampilan teknis dan lebih fleksibel serta mampu belajar mengenai pengetahuan dan keterampilan baru. Dunia usaha dan industri bukanlah sesuatu yang statis tetapi dinamis mengikuti perkembangan teknologi yang ada sehingga dalam mengidentifikasi kompetensi yang dibutuhkan dunia industri sangat subjektif dan berubah sesuai kebutuhan. Pendidikan di dunia kerja memberikan ilmu pengetahuan dan pengalaman yang tidak diperoleh di bangku sekolah, antara lain pembentukan wawasan mutu, wawasan keunggulan, wawasan pasar, wawasan nilai tambah, dan pembentukan etos kerja (Djojonegoro, 1998, p.71)

Upaya SMK untuk mencapai tujuan menciptakan lulusan yang siap kerja yaitu dengan melaksanakan Praktik Kerja Industri (Prakerin), yang siswa tersebut dapat memperoleh segala keterampilan, pengetahuan, dan sikap yang diberikan atau dicontohkan oleh pemilik perusahaan. Kelebihan dari SMK yaitu lulusan dapat mengisi peluang kerja pada DUDI. Sertifikat yang dapat dijadikan peluang kerja pada DUDI yaitu sertifikat yang diperoleh siswa melalui Ujian Kemampuan Kompetensi (UKK). Pelaksanaan UKK biasanya dilakukan siswa pada kelas XII. Berbagai upaya telah dilakukan SMK untuk meningkatkan mutu lulusan dan daya serap lulusan ke DUDI. Upaya tersebut harus mampu mendekatkan SMK dengan DUDI. Sekolah memberikan dasar-dasar kejuruan, sedangkan dunia kerja memberikan pengalaman kerja professional yang sarat akan nilai-nilai yang pada umumnya tidak didapat ketika di bangku sekolah.

Kondisi lingkungan praktik siswa harus dibuat replika dengan keadaan di tempat kerja (Prosser, 1925 dalam Wonacott, 2003, p.8). Replika yang dimaksud adalah kondisi lingkungan, alat kerja, tata ruang, bahan-bahan, dan waktu pengerjaan. Kondisi tersebut diharapkan dapat mengembangkan keterampilan yang diperlukan sesuai dengan keadaan di tempat industri. Suasana tempat kerja yang dikondisikan sama dengan tempat kerja diharapkan memiliki dampak pada kualitas dan kuantitas produksi yang dibuat oleh siswa.

Praktik Industri merupakan Proses perencanaan prakerin dimulai dari penetapan visi, misi, tujuan, sasaran prakerin. Hasil penelitian yang dilakukan oleh Rubiatun (2013) yang berkaitan dengan langkah proses peren- 
canaan harus dirinci terlebih dahulu sehingga setiap satuan kegiatan menjadi jelas baik mengenai sasaran, pelaksana, hasil yang diharapkan, waktu, sarana yang diperlukan, tahaptahap pelaksanaan, dan pembiayaan. Perencanaan kegiatan prakerin tentunya ada keterlibatan antara pihak DUDI dan pihak sekolah. Pihak sekolah peka terhadap perubahanperubahan kebijaksanaan yang dibuat oleh pemerintah dan yang terjadi di masyarakat sehingga dapat ditetapkan standar kompetensi bagi masing-masing jurusan/program studi atau bidang/program keahlian.

Kompetensi Lulusan SMK yang tidak sesuai dengan tuntutan dunia kerja akan menimbulkan suatu permasalahan yaitu daya serap lulusan SMK terhadap DUDI akan rendah. Idealnya, secara nasional lulusan SMK yang langsung dapat memasuki dunia kerja sekitar $80 \%-85 \%$ (Samsudi dalam Miswardi \& Pardjono, p.269, 2013). Menurut Setiadi (2014) Dikpora dan Dinas Nakertrans DIY berkoordinasi untuk mewujudkan sinergitas pendidikan terhadap pembangunan DIY, dikarenakan adanya sudut pandang yang berbeda antara dua instansi. Dikpora memandang apakah ada lowongan yang tersedia bagi lulusan SMK sedangkan Nakertrans memandang apakah ada lulusan SMK yang memiliki kompetensi sesuai dengan lowongan kerja. Berdasarkan kedua pandangan tersebut diharapkan adanya map yang memberikan informasi tentang ketersediaan lowongan kerja dengan kompetensi keahlian yang dibutuhkan, agar para siswa lulusan SMK dapat dengan mudah memilih pekerjaan yang sesuai. Menurut BPS (Badan Pusat Statistik) tahun 2013 angka keterserapan lulusan SMK di dunia kerja masih rendah, hal ini disebabkan kurangnya informasi yang diperoleh para lulusan, selain itu pola pikir siswa yang tidak berani atau tidak ada dukungan dari keluarga untuk mencoba bekerja di luar kota (Dikpora, 2014).

Berdasarkan observasi selama kegiatan pra survei ke sekolah, di SMK N 1 pengasih Kulon Progo khususnya Program Studi keahlian Tata Busana sebelum siswa diterjunkan dalam prakerin, guru mengadakan tes kemampuan untuk siswa. Tes kemampuan dilakukan dengan tujuan penyesuaian tempat prakerin dengan kemampuan peserta prakerin sehingga siswa dapat memilih tempat dan kompetensi apa yang mereka gemari. Akan tetapi hal tersebut tidak didukung komunikasi yang baik antara SMK N 1 Pengasih Kulon Progo dengan institusi pasangan DUDI. Komunikasi yang terjalin kurang mengarah kepada optimalisasi peranan masing-masing pihak dan mengidentifikasi kompetensi yang harus dikuasai siswa selama melaksanakan prakerin.

Model kerja sama yang menyentuh pada pembagian tugas yang terstruktur tentang apa yang dipelajari siswa di sekolah dan tata urutan pelatihan yang terstruktur di DUDI tersebut mengakibatkan siswa dituntut untuk berusaha secara mandiri untuk memperoleh kompetensi-kompetensi yaitu pencarian apa yang harus dipelajari dan dikuasai selama siswa melakukan kegiatan prakerin. Prakerin memungkinkan siswa memperoleh kompetensi-kompetensi yang belum didapat di bang$\mathrm{ku}$ sekolah sehingga setelah melaksanakan prakerin siswa diharapkan dapat mencapai tingkat keahlian yang jauh lebih baik. Dengan demikian perlunya pengkajian lebih dalam proses perolehan kompetensi siswa dalam melaksanakan Prakerin di DUDI busana butik khususnya DUDI yang memiliki pola pembimbingan yang berbeda

Pengkajian mengenai perolehan kompetensi tersebut diharapkan akan memberikan sumbangsih konsep teoretis dalam proses perolehan kompetensi melalui prakerin dan mendukung pengembangan kerangka pendidikan dan dapat dijadikan bahan referensi terkait dengan proses perolehan kompetensi prakerin busana butik.

Sudira (2011, p.23) berpendapat bahwa pendidikan kejuruan tidak lepas dari peran DUDI yang berfungsi untuk menjembatani antara DUDI dengan masyarakat untuk memberikan bekal kompetensi yang dibutuhkan. Kompetensi yang dibutuhkan tidak lepas dari kompetensi teknis dan kompetensi kepribadian sebagai bekal untuk meningkatkan posisi ekonomi di masyarakat.

UNESCO Revised Recommendation (2001) melalui website-nya mendefinisikan pendidikan kejuruan sebagai istilah yang komprehensif mengacu pada aspek-aspek yang melibatkan pada proses pendidikan. studi teknologi, akuisisi keterampilan praktis, sikap, pemahaman dan pengetahuan yang berkaitan dengan pekerjaan diberbagai sektor kehidupan ekonomi dan sosial. Sekolah kejuruan pada dasarnya menyiapkan siswanya untuk siap bekerja diberbagai sektor. 
Maclean, R., Wilson, D. \& Chinien, E., 2009) menyatakan bahwa pendidikan kejuruan focus pada perolehan pengetahuan dan keterampilan di dunia kerja untuk meningkatkan produktivitas kerja, keberlangsungan hidup, pengembangan pribadi, dan kemampuan personal dan pengembangan sosio-ekonomi

Berdasarkan beberapa pengertian tentang pendidikan kejuruan tersebut dapat disimpulkan, bahwa pendidikan kejuruan merupakan pendidikan yang mempersiapkan siswa untuk mampu memasuki dunia kerja sesuai bidang keahlian yang ditekuni.

Pernyataan tersebut diartikan bahwa pendidikan kejuruan sebagai lembaga yang komprehensif mengacu pada aspek-aspek yang melibatkan proses pendidikan, selain pendidikan umum, studi teknologi dan ilmu terkait, dan akuisisi keterampilan praktis, sikap, pemahaman dan pengetahuan yang berkaitan dengan pekerjaan diberbagai sektor kehidupan ekonomi dan sosial. Sekolah kejuruan pada dasarnya menyiapkan siswanya untuk siap bekerja.

Pendidikan kejuruan yang efektif harus memperhitungkan pembentukan kompetensi siswa dan penerapannya. Catts, Falk, \& Wallace $(2011$, p.7) mengatakan: pembelajaran pendidikan kejuruan yang efektif terdiri dari dua dimensi yang sangat penting, yaitu: (a) belajar sebagai perolehan pengetahuan kejuruan; dan (b) belajar secara kontekstual (sosial-politik dan budaya) dalam penerapan pengetahuan tersebut. Pembelajaran pendidikan kejuruan dapat efektif apabila proses pendidikan menggunakan konsep social partnerships. Konsep ini membutuhkan kerja sama antara dan melibatkan komunitas, para pekerja, dan situasi di tempat kerja. Dengan demikian, pembentukan kompetensi siswa dapat tercapai melalui konsep social partnerships, serta kompetensi yang diperoleh siswa dalam prakerin dapat diterapkan secara kontekstual.

Siswa dapat sukses dan berhasil dibutuhkan keterlibatan secara mendalam dan melatih teori-teori dengan praktik. Selain itu, penyebab siswa gagal dalam pembelajaran, rata-rata disebabkan oleh strategi pembelajaran terfokus pada local cues (Hosenfeld, 1997, dalam Broady \& Dwyer, 2008). Pengungkapan akuisisi pengetahuan, keterampilan, dan sikap saat pembelajaran dapat dilihat melalui kuesioner dan pengamatan secara men- dalam (OECD, 2010). Untuk itu pengungkapan akuisisi tersebut dapat berfungsi sebagai modal awal dalam pengembangan kompetensi setiap siswa.

Menurut Azwar (2007, p.60) sikap dapat dibentuk atau diubah melalui empat macam cara, yaitu: (1) adopsi, kejadian-kejadian dan peristiwa-peristiwa yang terjadi berulang dan terus-terusan, lama kelamaan secara bertahap ke dalam diri individu dan mempengaruhi terbentuknya sikap; (2) diferensiasi, dengan berkembangnya intelegensi, bertambahnya pengalaman, bertambahnya usia, maka ada hal-hal yang tadinya dianggap sejenis sekarang dipandang tersendiri lepas dari jenisnya; (3) intelegensi, tadinya secara bertahap dimulai dengan berbagai pengalaman yang berhubungan dengan suatu hal tertentu; dan (4) trauma, pengalaman yang tiba-tiba, mengejutkan yang meninggalkan kesan mendalam pada jiwa orang yang bersangkutan.

Work based learning (pembelajaran berbasis kerja) adalah aspek penting untuk keberhasilan sebuah organisasi atau instansi. WBL merupakan bagian dari pendekatan school to work transition yang mana mencakup pembelajaran berbasis sekolah dan menghubungkan aktivitas di dunia kerja (Cunningham, 2004, p.6).

Kompetensi baru yang dilakukan oleh siswa dapat diperoleh melalui diskusi yang dilakukan dengan sesama teman kerja. Chun Wei Choo (2006, p.xii) menyatakan bahwa terdapat beberapa cara untuk memperoleh pengetahuan baru, salah satunya tercantum pada poin ketiga. Poin tersebut menyatakan bahwa pengetahuan baru dapat diperoleh melalui diskusi dan berbagi pengetahuan yang ada.

Situated learning merupakan pembelajaran yang berkontribusi terhadap tumbuhnya penelitian dalam human sciences untuk mengeksplorasikan pemahaman karakter manusia terhadap komunikasi. Hal ini dibutuhkan hubungan yang fokus antara belajar dan situasi sosial yang terjadi (Lave \& Wenger, 1990).

Kurikulum untuk pendidikan kejuruan dikembangkan berdasarkan beberapa faktor, yaitu internal dan eksternal. Melalui kurikulum, siswa dapat belajar dari awal pembelajaran sampai perkembangan kompetensi lebih lanjut hingga lulus. Tidak hanya perancangan di sekolah saja, kurikulum praktik 
kerja di industri harus diidentifikasi, dikonseptualisasi dan dievaluasi. Tanpa adanya identifikasi, konseptualisasi dan pengakuan dari kurikulum berbasis tempat kerja, maka tempat kerja akan tetap disalahpahami sebagai tempat belajar (Billet dalam Miswardi \& Pardjono, 2013, p.278)

Menurut Harjono (2012:65) Perancangan Program Prakerin tidak terlepas dari implementasi silabus kedalam pembelajaran, yang membutuhkan metode, strategi dan evaluasi pelaksanaan yang sesuai. Rancangan prakerin sebagai bagaian pembelajaran perlu memperhatikan kesiapan Dunia Kerja mitra dalam melaksanakan pembelajaran kompetensi tersebut.

Hal ini diperlukan agar dalam pelaksanaan dan penempatan siswa untuk prakerin tepat sasaran sesuai kompetensi yang akan dipelajari. Langkah-langkah yang perlu dilakukan adalah: Pertama, evaluasi pencapaian kompetensi hasil pembelajaran di sekolah Evaluasi memberikan masukan kepada siswa maupun pembimbing itu sendiri. Dengan adanya evaluasi siswa dan pembimbing akan diketahui kekurangan yang ada pada dirinya masing-masing, sehingga akan dengan mudah untuk dilakukan perbaikan.

Menurut Mudjiman (2007, p.7) belajar mandiri adalah kegiatan belajar aktif, yang didorong oleh niat atau motif untuk menguasai sesuatu kompetensi guna mengatasi sesuatu masalah, dan dibangun dengan bekal pengetahuan atau kompetensi yang telah dimiliki. Belajar mandiri menjadikan siswa dapat memecahkan sebuah masalah. Siswa menjadi terbiasa dalam memecahkan sebuah masalah ketika melakukan pekerjaan.

Menurut Jonassen (2011, p.241) tujuan dari belajar memecahkan masalah tidak hanya menemukan solusi setiap masalah, tetapi mampu mengenali masalah serupa dikemudian hari untuk mengurangi usaha yang diperlukan untuk memecahkan masalah transfer pada waktu tersebut. Apabila mampu memecahkan sebuah masalah, siswa akan lebih cepat dalam mengerjakan sebuah pekerjaan apabila menjumpai masalah yang sama. Apabila siswa mampu memecahkan masalah yang dihadapi, secara tidak langsung telah mendapatkan sebuah kompetensi.

Prakerin dapat digunakan sebagai tempat belajar pada aspek budaya dan sosial. Proses pembelajaran membutuhkan perpaduan dengan jaringan sosial yang sering diabaikan (Singh, 2009, p.352). Hal ini mengakibatkan terjadinya perbedaan perolehan kompetensi yang dimiliki. Penerapan kompetensi pada setiap daerah sangat berbeda dengan daerah lain. Oleh karena itu, siswa dituntut untuk mempelajari kompetensi pada aspek sosialbudaya ditempat kerja.

Berdasarkan uraian tersebut, maka penelitian ini berutjuan untuk mengetahui perolehan kompetensi siswa di setiap DUDI, khususnya busana butik yang memiliki pola pembimbingan berbeda. Penelitian ini menggunakan jenis penelitian studi kasus pendekatan kualitatif.

\section{METODE PENELITIAN}

Penelitian ini menggunakan jenis penelitian studi kasus dengan pendekatan kualitatif. Penelitian ini dilaksanakan selama enam bulan mulai tanggal 1 Oktober 2014 sampai dengan Februari 2015. Penelitian ini berlokasi di SMK N 1 Pengasih Jl. Pengasih no 11, Kulon Progo, Daerah Istimewa Yogyakarta. Pemilihan lokasi ini karena sekolah SMK N 1 Pengasih merupakan salah satu SM$\mathrm{K}$ di kabupaten kulon progo yang termasuk dalam daftar rintisan SMK rujukan. Selain di SMKN 1 Pengasih, penelitian dilakukan di industri pasangan SMK N 1 Pengasih yaitu di L'Mar Butik, sanggar busana Goet Puespo dan Puspa Rini sebagai industri pasangan SMKN 1 Pengasih.

Unit analisis dalam penelitian ini adalah perolehan kompetensi oleh siswa dalam program praktik industri pada bidang keahlian busana butik sekolah menengah kejuruan.

Sumber data pada penelitian ini adalah orang-orang yang memiliki kapasitas sebagai sumber informasi/informan penelitian. Informan yang dilibatkan pada penelitian ini berjumlah 13 orang terdiri dari enam siswa, dua guru/pembimbing prakerin, tiga instruktur industri atau yang berwenang di industri dan dua ahli kompetensi busana butik. Inisial Informan penelitian ini yaitu Ibu RN selaku pembimbing/guru di sekolah yang bertugas memonitoring kegiatan prakerin di L'Mar Butik, Ibu ES selaku pembimbing/guru di sekolah yang bertugas memonitoring kegiatan prakerin di Goet Poespo, DN selaku instruktur/pembimbing prakerin di L'Mar Butik, AL selaku Instruktur/pembimbing prakerin di 
sanggar busana Goet Poespo, ASY selaku Instruktur/pembimbing prakerin di Puspa Rini, RN dan WW selaku ahli pada bidang kompetensi busana butik, SPT dan OV selaku siswa prakerin di L'Mar Butik, WD dan SM selaku siswa prakerinn di Goet Poespo, dan AP, IS selaku siswa prakerinn di Puspa Rini.

Teknik dan instrumen pengumpulan data meliputi data observasi partisipatif, wawancara secara mendalam, dan dilengkapi dengan dokumentasi. Validitas data dicek menggunakan teknik validitas internal dan external triangulation. Teknik validitas internal triangulation dilakukan dengan cara memunculkan data yang sama dari orang yang sama dengan menggunakan teknik yang berbeda. Sementara itu, teknik validitas external triangulation dilakukan dengan cara membandingkan laporan dari berbagai informan.

Teknik analisis data yaitu model interaktif Miles \& Huberman, meliputi pengumpulan data, data condensation, penyajian data, verifikasi, dan penarikan kesimpulan.

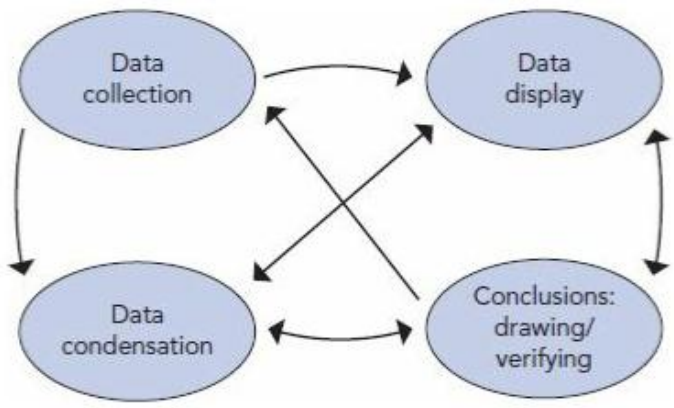

(Miles, Huberman, \& Saldaña, 2014, p.10)

Gambar 1. Komponen Analisis Data

\section{HASIL PENELITIAN DAN PEMBAHASAN}

\section{Temuan Praktik Kompetensi keahlian Tata Busana}

Temuan kompetensi yang muncul ketika siswa melaksanakan Prakerin di tempat industri sangat bervariasi, tergantung dari jenis/bidang busana yang akan diproduksi dan jasa yang ditawarkan oleh setiap industri. Praktik yang muncul saat melaksanakan prakerin sebelumnya telah dapat diperkirakan sesuai kehendak dari siswa itu sendiri. Hal itu dikarenakan dengan menentukan lokasi prakerin tersebut secara otomatis dapat diketahui jenis praktik yang akan muncul saat siswa melaksanakan prakerin.berikut ini adalah praktik yang muncul ketika siswa prakerin di L'Mar butik, Goet Poespo, dan Puspa Rini

L'Mar Butik merupakan salah satu DU/DI mitra SMK N 1 Pengasih yang telah bekerja sama dalam waktu cukup lama. L'Mar Butik merupakan jenis usaha busana yang bergerak dibidang jasa dan produksi. Spesifikasi busana yang diproduksi di L'Mar Butik adalah produksi busana pesta dan busana show baik busana pria maupun wanita. Praktik yang muncul ketika siwa prakerin yaitu mendesain busana pesta dan busana show, menjahit kebaya dan busana pesta, menghias busana, finishing.

Goet Puspo adalah seseorang yang ahli dalam bidang pola jenis usaha busana yang dimiliki oleh Goet Poespo bergerak di bidang jasa dan produksi. Spesifikasi Busana yang di produksi di Goet Poespo adalah produksi busana ready to wear. Dimensi-dimensi praktik yang muncul ketika siswa prakerin di Goet Poespo yaitu mengerjakan fragment payet kemudian dilanjutkan menjahit celana, membuat alat bantu press, membuat pinkusion, membuat jumpsuit, playsuit, menjahit bantalan jarum, rok, blazer, rompi vest dan mengepres (finishing).

Puspa Rini adalah seseorang yang ahli dalam bidang fashion. Jenis usaha busana bergerak di bidang jasa dan produksi. Spesifikasi Busana yang diproduksi di Puspa Rini adalah produksi busana kebaya dan pengantin beserta aksesorisnya. Dimensi praktik yang muncul ketika siswa prakerin di Puspa Rini yaitu awalnya siswa mengerjakan pekerjaan finishing seperti menyetrika pesanan pelanggan, mengemas kebaya kemudian dilanjutkan dengan memasang payet pada sepatu penganti (slop), dress, ekor busana pengantin, kebaya.

Berdasarkan hasil penelitian di lapangan, peneliti menemukan bahwa dimensi praktik yang sering muncul ketika siswa melakukan prakerin yaitu membuat busana wanita, membuat busana pria, menghias busana. Kompetensi tersebut muncul karena jenis produksi dan penawaran jasa dari ketiga industri untuk penelitian sebagian besar membuat busana wanita dan sebagian membuat busana pria baik busana ready to wear maupun busana pesta.

Kompetensi yang diperoleh siswa juga tergantung pada divisi kerja yang diberikan kepada siswa. Dari tiga belas informan yang diwawancarai semuanya menunjukkan jawab- 
an yang diberikan mengarah pada divisi penjahitan (sewing) dan divisi menghias dan penyelesaian (finishing). Divisi pembuatan pola dan pemotongan bahan (cutting) diberikan kepada sebagian siswa karena pseserta didik masih belum dipercaya sepenuhnya pada divisi tersebut. Proses produksi yang muncul relevan dengan pendapat Jerusalem (2012, p.25) bahwa "sistem produksi busana butik secara menyeluruh pada prinsipnya adalah menyelesaikan satu produk butik hingga selesai terlebih dahulu baru mengerjakan produk butik lainnya"

\section{Pengelompokkan Aspek kompetensi berdasarkan Standar Kompetensi Busana Butik}

Berdasarkan temuan data-data dari lapangan, kompetensi yang muncul terdiri darii tiga aspek yaitu aspek kognitif (pengetahuan), afektif (sikap), psikomotorik (keterampilan) tersebut dapat dikelompokkan berdasarkan standar kompetensi yang ada disekolah. Secara umum aspek kognitif yang muncul ketika siswa melakukan prakerin yaitu pengetahuan tentang dunia kerja busana khususnya pembuatan busana dengan teknik butik yaitu teknik yang dituntut kerapihan. Pembuatan busana tersebut memiliki tahap-tahap sebagai berikut: (1) pembuatan desain busana; (2) pembuatan pola; (3) pemotongan bahan (cutting); (4) penjahitan (sewing); (5) pengerjaan akhir (finishing). Skema proses produksi butik tersebut sesuai dengan pendapat Jerusalem (2012, p.28). Produktivitas yang dilakukan oleh siswa merupakan kunci utama dalam membangun kontruksi suatu pengetahuan. Belajar kognitif melibatkan proses pengenalan dan atau penemuan. Selaras dengan pendapat Suparman (1997, p.99) bahwa perilaku kognitif adalah perilaku yang merupakan hasil proses berfikir. Semakin aktif siswa mencari informasi mengenai produktivitas yang dilakukan semakin banyak pengetahuan yang akan diperoleh. Pengetahuan tersebut yaitu pengetahuan tentang prosedur pembuatan busana seperti busana pesta, busana show, busana pengantin, kebaya, asesoris pengantin dan cara menghiasnya. Selain itu, kegiatan mengulangi pekerjaan yang sebelumnya telah dikerjakan dan keterlibatan dalam memecahkan suatu masalah pekarjaan merupakan pengalaman yang akan menambah pengetahuan siswa. Pengetahuan yang diperoleh siswa tersebut dapat dijadikan suatu referensi atau bekal siswa untuk memasuki dunia kerja, baik bekerja di industri maupun menjadi wirausahawan. Perilaku kognitif siswa yang muncul relevan dengan pendapat Bloom dalam Suparman (1997, p.98) membagi kawasan kognitif menjadi enam tingkatan yaitu pengetahuan, pemahaman, penerapan, analisis, sintesis, dan evaluasi.

Pada aspek afektif, ketika siswa melakukan prakerin secara tidak langsung akan membentuk sikap yang disesuaikan dengan budaya kerja di DUDI. Jam kerja rata-rata delapan jam/hari dengan begitu akan membentuk sikap siswa yang disiplin dan bekerja keras. Selain itu, pekerjaan yang dipercayakan kepada siswa akan membentuk sikap tanggung jawab dan kemandirian. Jika kepercayaan itu ternyata tidak sesuai, misalnya terjadi kecelakaan kerja maka siswa lebih memiliki rasa hati-hati terhadap pekerjaan yang akan dikerjakan selanjutnya. Proses belajar afektif menentukan bagaimana siswa menghubungkan dirinya dengan pengalaman baru. Perilaku afektif yang muncul relevan dengan pendapat Bloom (dalam Suparwan 1997, p.99) yang membagi kawasan afektif menjadi lima tingkatan yaitu menerima nilai, memebuat respon terhadap nilai, mengorganisasaikan nilai, dan mengamalkan nilai secara konsisten atau karakterisasi.

Aspek psikomotor merupakan kemampuan untuk melaksanakan suatu tugas tertentu baik secara fisik maupun mental. Untuk mengembangkan aspek psikomotor siswa, guru maupun instruktur industri memberikan petunjuk secara verbal tentang langkah-langkah yang harus ditempuh siswa untuk menguasai suatu keterampilan. Keterampilan yang diperoleh siswa pada saat melaksanakan prakerin merupakan suatu produktivitas kerja yang sangat penting bagi setiap industri. Dengan adanya produktivitas kerja diharapkan pekerjaan akan terlaksana secara efisien dan efektif sehingga tujuan yang telah ditetapkan akan dicapai. Pendapat tersebut didukung oleh Sutrisno $(2009$, p.99) bahwasannya produktivitas adalah ukuran efisiensi produktif. Produktivitas tersebut dapat berupa menyelesaiakan pekerjaan sesuai instruksi dari instruktur industri, mengerjakan pekerjaan sesuai teknik yang di terapkan di industri, dan mengerjakan pekerjaan yang seharusnya menjadi tanggung jawab siswa. Pekerjaan tersebut meliputi men- 
desain busana pesta wanita, menjahit busana pesta, busana pengantin, busana show, kebaya, membuat assesoris busana, dan menghias busana. Perilaku yang dikerjakan siswa tersebut merupakan perilaku pada kawasan psikomotor. Hal tersebut relevan dengan pendapat Dave Atwi Suparwan (1997, p.99) membagi kawasan psikomotor dalam lima jenjang perilaku yaitu menirukan gerak, memanipulasikan kata-kata menjadi gerak, melakukan gerak dengan tepat, merangkaikan berbagai gerak, dan melalkuakn gerak dengan gerak wajar dan efisien.

\section{Cara Memperoleh Keahlian Tata Busana}

Kompetensi-kompetensi diharapkan lahir dari setiap proses yang diikuti oleh siswa selama melaksanakan prakerin. Setiap proses memiliki tantangan tersendiri bagi siswa. Rancangan kegiatan prakerin yang baik dapat meningkatkan kompetensi siswa. Lingkungan kondusif yang diciptakan dalam prakerin akan mendorong munculnya berbagai bentuk kompetensi dan yang tak kalah penting adalah siswa dapat melakukan learning by doing. Perolehan kompetensi tidak dapat dilakukan dengan pemberian teori tetapi terbentuk karena pengalaman dan kepercayaan yang diberikan kepada siswa dan didukung dengan lingkungan di sekelilingnya. Berikut cara perolehan kompetensi yang dilakukan siswa saat melaksanakan prakerin

Pertama, komunikasi yang aktif dan kerja sama yang baik dengan orang-orang yang terlibat pada pelaksanaaan prakerin sangat diperlukan agar terjadi komunikasi yang terarah sehingga pekerjaan akan jelas dan lancar.

Kedua, penggunaan teknik belajar yaitu melihat, mendengar dan melakukan. Siswa melihat instruktur pada saat memberikan contoh (unjuk kerja), melihat sampel yang telah dibuat oleh instruktur industri, melihat karyawan lain mengerjakan pekerjaan yang serupa dengan pekerjaan yang peserta didik sedang lakukan. Dengan melihat, peserta didik dapat mengetahui teknik dan langkah kerja yang harus dilakukan terhadap pekerjaaannya. dapat mendengar semua instruksi dan masukan dari instruktur industri. Ketika instruktur industri memberikan pengarahan mengenai pekerjaan peserta didik mendengarkan kemudian memahami apa yang instruktur sampai- kan. Informasi yang telah di dapat oleh peserta didik dengan cara melihat, mendengar kemudian di wujudkan melaui praktik langsung dengan pekerjaan yang dihadapinya. Dengan begitu, peserta didik akan mengetahui kekurangan maupun kelebihan dari setiap pekerjaan yang telah dilakukan

Ketiga, penggunaan metode kerja yang tepat, praktis, cepat dan aman. Untuk dapat menetapkan metode pengerjaan yang tepat dibutuhkan keterampilan instruktur industri untuk memberikan pengarahan bagaiamana cara/teknik yang digunakan dalam menyelesaikan suatu pekerjaan.

Keempat, bekerja secara mandiri. Pada saat prakerin peserta didik mampu mengorganisir sendiri pekerjaannya dengan baik sesuai target yang diharapkan tanpa harus diberikan pengarahan secara mendetil oleh instruktur industri. Hal tersebut dapat meningkatkan rasa percaya diri bagi peserta didik karena peserta didik mencoba menyelesaikan pekerjaan secara mandiri dengan bekal pengetahuan dan pengalaman yang peserta didik miliki.

Kelima, bekerja dengan rasa tanggung jawab yang sungguh-sungguh. Kesadaran akan peran dan tanggung jawab terhadap pekerjaan memegang peran yang sangat penting. Setiap pekerjaan yang peserta didik kerjakan harus dipertanggungnjawabkan. Apabila kurang sesuai dengan standar mutu yang diterapkan di industri, peserta didik siap menerima resiko dan bertanggung jawab menyelesaikan pekerjaan sesuai waktu yang telah ditetapkan. Dengan begitu, peserta didik secara tidak langsung memperoleh sikap tanggung jawab dan disiplin dalam menyelesaikan suatu pekerjaan.

Keenam, memegang teguh etos kerja. Secara tidak langsung, peserta didik yang melakukan prakerin akan mengikuti aturan-aturan yang bersifat mengikat dan ditetapkan. Secara eksplisit hal tersebut yang dinamakan etos kerja. Etos kerja merupakan salah satu faktor penentu keberhasilan untuk meningkatkan produktivitas kerja, misalnya dalam melakukan pekerjaan menjahit peserta lebih peduli tentang kualitas dan mutu yang diterapkan di industri yang mereka tempati.

Ketujuh, pengorganisasian dan implementasi yang baik dalam bekerja. Jika dihubungkan dengan organisasi pada suatu industri, pengorganisasian kerja adalah pembagian kerja. Pengorganisasian merupakan rincian pengelompokkan aktivitas/pekerjaan yang 
berkaitan satu dengan yang lainnya untuk mencapai satu tujuan tertentu.

Kedelapan, melakukan pekerjaan berdasarkan kepercayaan yang di berikan oleh instruktur indutri (pembimbing industri). Kepercayaan yang diberikan instruktur kepada peserta didik diwujudkan pada keterlibatan peserta didik pada pembuatan suatu produk. Kepercayaan pekerjaan yang diberikan kepada peserta didik merupakan pengalaman yang dapat dijadikan pengetahuan oleh peserta didik. Semakin tinggi tingkat kepercayaan intruktur kepada peserta didik, maka semakin banyak pula pekerjaan yang harus dikerjakan oleh peserta didik

Kesembilan, melakukan pekerjaan yang sebelumnya belum pernah dikerjakan (pengembangan diri). Kompetensi akan terbentuk apabila dilakukan secara integratif dan menyeluruh. Hal ini terbukti pada peserta didik yang mengikuti prakerin secara utuh dan berkelanjutan. Bagi mereka yang total mengikuti prakerin secara serius dan terus menerus dan berani mencoba pekerjaan yang sebelumnya belum pernah dikerjakan akan terlihat perbedaannya dalam kemampuan berbicara, mengemukakan ide dan pendapat, keberanian memimpin dan berinisiatif. Kemampuan-kemampuan ini merupakan pembaharuan kompetensi yang sebelumnya tidak didapat di bangku sekolah.

Kesepuluh, menerapkan kompetensi yang telah didapat dari sekolah. Kompetensi yang telah didapatkan di bangku sekolah, dapat di terapkan pada saat prakerin, misalnya teknik dasar menjahit busana. Hal tersebut dapat digunakan untuk membandingkan teknik yang ada di sekolah dan di industri. Dengan begitu peserta didik akan mengetahui kekurangan dan kelebihan dari masing-masing teknik tersebut.

\section{Pencapaian Kompetensi Siswa}

Berdasarkan kompetensi yang diperoleh peserta didik setelah melakukan prakerin, dapat dikatakan berhasil mencapai Kriteria Ketuntasan minimal (KKM) yaitu dengan nilai $<7,00$. Kriteria pencapaian kompetensi di setiap industri berbeda-beda. Pada dasarnya semua tergantung dari kompetensi yang dimiliki owner pada setiap industri. Jika peserta didik saat prakerin ditangani langsung oleh owner industri yang kompeten di bidang busana dan mau memberikan ilmu-ilmunya kepada peser- ta didik dan memberikan kesempatan, kepercayaan peserta didik untuk belajar dan mencoba mengerjakan pekerjaan yang ada di industri maka kompetensi yang akan diperoleh peserta didik akan maksimal

Pencapaian kompetensi yang diperoleh peserta didik di SMK N 1 Pengasih kompetensi keahlian busana butik belum dapat dikatakan memenuhi standar DUDI, masih butuh pemantapan mental dan pengalaman untuk memasuki dunia kerja yang sebenarnya. Level Kompetensi peserta didik yang prakerin di Goet Poespo dan Puspa Rini berada pada posisi Pemula (novices) yaitu peserta didik baru dalam suatu situasi kerja (lihat Gambar 1) masih ada beberapa perbaikan untuk pekerjaan sebelumnya. Peserta didik perlu menambah pengalaman, pengetahuan dan keterampilan untuk memenuhi persyaratan yang dibutuhkan untuk melakukan pekerjaan tertentu, sedangkan di L'Mar butik berada pada posisi specialist (lihat gambar 2) yaitu dapat diandalkan untuk melakukan pekerjaan yang spesifik tanpa pengawasan tetapi terbatas pada pekerjaan rutin. Hal ini sepedapant dengan Jacob \& Washington, (2003, p.6) yang membagi Level Kompetensi Manusia dalam Bekerja menjadi lima yaitu: (1) pemula (novice); (2) specialist; (3) specialist berpengalaman; (4) ahli; dan (5) master.

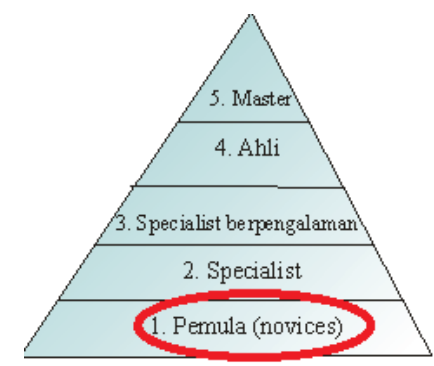

Gambar 2. Level Kompetensi Siswa yang Prakerin di Goet Poespo dan Puspa Rini

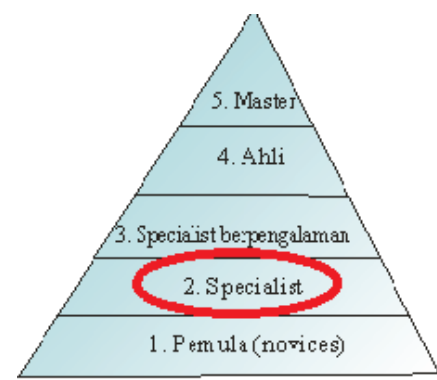

Gambar 3. Level Kompetensi Siswa yang Prakerin di L'Mar Butik 


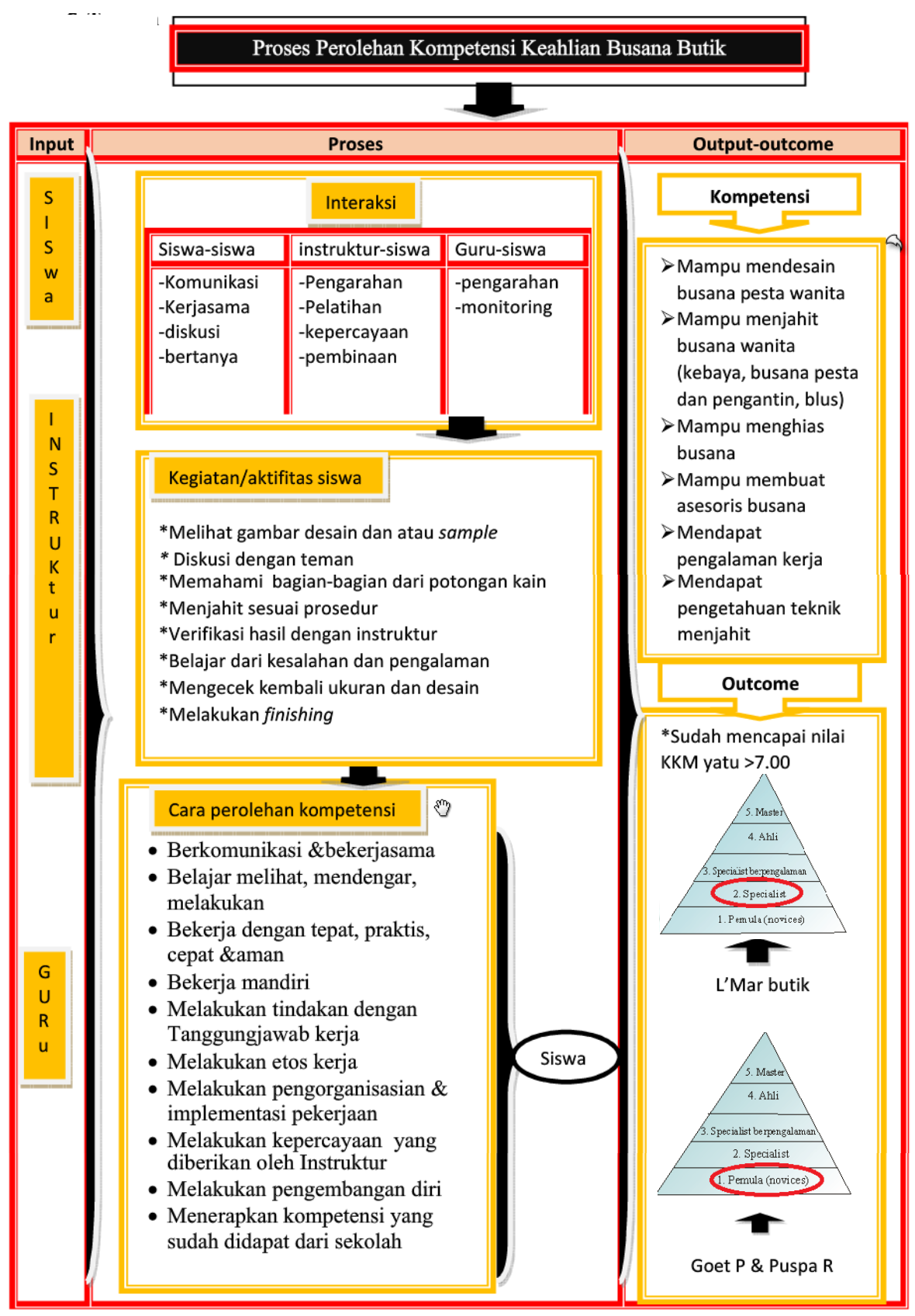

Gambar 4. Proses Perolehan Kompetensi Siswa di DU-DI

\section{Temuan Penelitian}

SMK sebagai lembaga pendidikan dapat dipandang sebagai sistem yang terdiri dari input, proses dan output dan mengahasilkan income. Untuk menjadikan input menjadi suatu output yang baik ataupun berkualitas, maka diperlukan proses yang baik pula. Berikut ini adalah bagan proses perolehan kompetensi yang dilakukan siswa SMK N 1 Pengasih saat melaksanakan prakerin.

Pada saat mengikuti kegiatan Prakerind, siswa melakukan serangkaian kegiatan. Ke- giatan tersebut dilakukan siswa untuk memperoleh kompetensi baru yang ada di industri maupun untuk mengembangkan kompetensi yang sudah didapatkan dibangku sekolah. Pada Gambar 4 merupakan alur proses perolehan kompetensi siswa ketika mengikuti kegiatan Prakerind di DU-DI.

Pada Gambar 4 dapat dijelaskan bahwa siswa melalui serangkain kegiatan untuk mendapatkan sebuah kompetensi. Berikut penjelasan Gambar 4. 
Siswa, instruktur dan guru merupakan objek yang terlibat dalam pelaksanaaa prakerin kegiatas yang dilakukan oleh siswa seperti melihat gambar desain dan atau sample, diskusi dengan teman, memahami bagianbagian dari potongan kain, menjahit sesuai prosedur, verifikasi hasil dengan instruktur, belajar dari kesalahan dan pengalaman, mengecek kembali ukuran dan desain, melakukan finishing

Kompetensi dapat diperoleh siswa melalui (1) komunikasi aktif dan kerja sama yang baik; (2) penggunaan teknik belajar yaitu mendengar, melihat dan melakukan; (3) penggunaan metode erja yang tepat, praktis, cepat dan aman; (4) bekerja secara mandiri; (5) bekerja dengan rasa tanggung jawab yang sungguh-sungguh; (6) memegang teguh etos kerja; (7) pengorganisasian dan implementasi yang baik dalam bekerja; (8) melakukan pekerjaan berdasarkan kepercayaan yang di berikan oleh instruktur industri (pembimbing industri); (9) melakukan pekerjaan yang sebelumnya belum pernah dikerjakan (pengembangan diri); (10) menerapkan kompetensi yang sudah didapat dari sekolah.

Setelah melalui proses yang dilakukan berulang-ulang, siswa telah mendapatkan kompetensi baru maupun mengembangkan kompetensi yang sudah didapatkan dibangku sekolah. Kompetensi yang didapatkan siswa diantaranya yaitu siswa: mampu mendesain busana pesta wanita, mampu menjahit busana wanita (kebaya, busana pesta dan pengantin, blus), mampu menghias busana, mampu membuat asesoris busana, mendapat pengalaman kerja, mendapat pengetahuan teknik menjahit

Kompetensi yang diperoleh peserta didik setelah melakukan prakerin, dapat dikatakan berhasil mencapai Kriteria Ketuntasan minimal (KKM) yaitu dengan nilai < 7,00. Kompetensi peserta didik yang prakerin di Goet Poespo dan Puspa Rini berada pada posisi Pemula (novices) yaitu peserta didik baru dalam suatu situasi kerja masih ada beberapa perbaikan untuk pekerjaan sebelumnya. Peserta didik perlu menambah pengalaman, pengetahuan dan keterampilan untuk memenuhi persyaratan yang dibutuhkan untuk melakukan pekerjaan tertent. Sedangkan di L'Mar butik berada pada posisi specialist yaitu dapat diandalkan untuk melakukan pe- kerjaan yang spesifik tanpa pengawasan tetapi terbatas pada pekerjaan rutin.

\section{SIMPULAN DAN SARAN}

\section{Simpulan}

Hasil penelitian ini dapat disimpulkan sebagai berikut. Pertama, dimensi praktik yang muncul ketika siswa prakerin di setiap industri berbeda-beda. Tergantung jenis produksi busana dan jasa yang ditawarkan di setiap industri masing-masing. Pada umumnya praktik yang muncul merupakan standar kompetensi yang sudah tertuang pada kurikulum sekolah yaitu standar kompetensi pembutan busana wanita I, pembutan busana wanita II, pembuatan busana pria, membuat hiasan pada busana, mengawasi mutu pekerjaaan busana, menerapkan prosedur K3LH dalam bekerja, teknik menjahit busana, memilih bahan baku busana

Kedua, pengelompokan kompetensi yang muncul berdasarkan standar kompetensi sekolah yaitu pada aspek kognitif siswa memperoleh pengetahuan tentang dunia kerja busana khususnya teknik yang diterapkan pada busana butik yang menuntut kerapian. Berdasarkan standar kompetensi yang muncul siswa dapat memperoleh pengetahuan mengenai teknik pembuatan busana dari setiap tahap pekerjaan yang siswa kerjakan. Pada aspek afektif siswa secara tidak langsung akan membentuk sikap yang disesuaikan dengan budaya kerja yang diterapkan di DUDI. Aspek psikomotor merupakan keterampilan yang diperoleh siswa saat menyelesaikan pekerjaan di tempat kerja

Ketiga, cara perolehan kompetensi yang dilakukan siswa saat melaksanakan prakerin yaitu: (1) komunikasi aktif dan kerja sama yang baik; (2) penggunaan teknik belajar yaitu mendengar, melihat dan melakukan; (3) penggunaan metode kerja yang tepat, praktis, cepat dan aman; (4) bekerja secara mandiri; (5) bekerja dengan rasa tanggung jawab yang sungguh-sungguh; (6) memegang teguh etos kerja; (7) pengorganisasian dan implementasi yang baik dalam bekerja; (8) melakukan pekerjaan berdasarkan kepercayaan yang di berikan oleh instruktur industri (pembimbing industri); (9) melakukan pekerjaan yang sebelumnya belum pernah dikerjakan 
(pengembangan diri); (10) menerapkan kompetensi yang sudah didapat dari sekolah.

Keempat, pencapaian kompetensi yang sudah diperoleh siswa sudah memenuhi nilai KKM yaitu $<7,00$. Kriteria pencapaian kompetensi pada setiap DUDI berbeda-beda tergantung dari tingkat kompetensi yang dimilki oleh instruktur dan atau pemilik industri. Level kompetensi siswa dalam bekerja di l'Mar Butik berada pada posisi spesialist yaitu siswa yang dapat diandalkan untuk melakukan pekerjaan tanpa pengawasan, sedangkan di Goet poespo dan Puspa Rini berada pada posisi pemula (novices) yaitu siswa baru dalam suatu situasi kerja.

\section{Saran}

Berdasarkan hasil penelitian tentang kajian perolehan kompetensi, maka terdapat beberapa saran berikut ini.

Sekolah atau guru kompetensi keahlian busana butik, hendaknya mengidentifikasi kompetensi di tempat kerja yang sesuai dengan kompetensi yang ada di sekolah. Setelah diidentifikasi, siswa diberikan materi yang sesuai untuk dipelajari dan sebagai panduan selama pelaksanaan.

Unsur pimpinan dan manajemen DUDI perlu memperhatikan proses pembelajaran Prakerind tersebut. Program Prakerind dapat menjadi titik awal siswa memperoleh kompetensi dan mendapatkan pengalaman yang berharga. Hal ini sebenarnya dapat menguntungkan bagi pihak DU-DI, karena tidak perlu men-training kembali siswa setelah lulus. Selain itu, siswa akan mempunyai nilai maanfat bagi pihak DU-DI ketika sedang banyak pekerjaan yang harus segera diselesaikan. Dengan pendampingan yang intensif, siswa akan dengan mudah melakukan sebuah pekerjaan yang ada di DU-DI.

\section{DAFTAR PUSTAKA}

Azwar, S. (2007). Sikap manusia: Teori dan pengukurannya (Edisi 2). Jakarta: Rineka Cipta

Broady, E. \& Dwyer, (2008). Bringing the learner back into the process: identifying learner strategies for grammatical development in independent language learning. In Singleton, D. (eds.), Language learning strategies in independent settings: Second language acquisition (pp. 141-158). UK: British Library.

Catts, R., Falk, I., \& Wallace, R. (2011). Introduction: Innovations in theory and practice. In Ralph Catts, Ian Falk \& Ruth Wallace, Vocational learning innovative theory and practice. New York: Springer. p. $1-8$.

Chun Wei Choo. (2006). The knowing organization: How organizations use information to construct meaning, create knowledge, and make decisions, second edition. New York: Oxford University Press.

Cunningham, I., Dawes, G., \& Bennett, B. (2004). The handbook of work based learning. Burlington: Gower Publishing Limited.

Dikpora. (2014, Februari 28). Seminar program sinergitas pendidikan terhadap pembangunan kegiatan Penelitian dan pembangunan Pendidikan. Dinas Dikpora DIY. http://dikpora.jogjaprov. go.id/dinas_v4/?view=v_berita\&id_sub =2995. Di akses pada tanggal 16 November 2014 pkl 14.00 WIB

Harjono, I .(2012). Implementasi Praktik Industri (Prakerin) pada Kompetensi Keahlian Teknik Instalasi Tenaga Listrik SMK Negeri 4 di Kota Tangerang. Tesis. Universitas Indonesia

Jacobs, R. L. (2003). Structured on-the-job training: unleashing employee expertise in the workplace. San Fransisco: Berrett-Koehler Publisher, Inc.

Jerusalem. A (2012). Membuka Usaha Butik. Klaten: PT Intan Sejati

Jonassen, David H. (2011). Learning to solve problems: A handbook for designing problem-solving learning environments. New York: Routledge

Lave, J., \& Wenger, E. (1990). Situated Learning: Legitimate peripheral participation. Cambridge, UK: Cambridge University Press.

Maclean, R., Wilson, D., \& Chinien, E. (2009). International handbook of education for the changing world of 
work, bridging academic and vocational learning. Germany: Springer.

Miles, M.B., Huberman, A.M., \& Saldaña, J. (2014). Qualitative data analysis: A methods sourcebook (3rd edition). Arizona: SAGE Publications, Inc.

Miswardi, Y., \& Pardjono, P. (2013). Proses dan Hasil Belajar pada Prakerind Bidang Keahlian Kendaraan Ringan: Studi Kasus pada Industri Pasangan SMKN 3 Yogyakarta. Jurnal Pendidikan Vokasi, 3(2). Retrieved from http:// journal.uny.ac.id/index.php/jpv/article/ view/1606

Mudjiman, H. (2007). Belajar Mandiri. Surakarta:UNS Press.

Rubiatun, N. (2013). Pengelolaan Praktik Kerja Industri Program Keahlian Pekerjaan Sosial ( Studi Kasus di SMK Negeri 8 Semarang Tahun 2013). Tesis. Ikip PGRI Semarang

Setiadi, E. (februari 2014). Sinergitas Pendidikan. Makalah disajikan dalam seminar Program Sinergitas Pendidikan terhadap pembangunan kegiatan penelitian dan pembangunan pendidikan untuk jenjang SMK, di Hotel Ros-In Yogyakarta

Sudira, P. (2011). Praksis ideologi tri hita karana dalam kebudayaan kompetensi pada SMK Di Bali. Disertasi. Universitas Negeri Yogyakarta. Diakses tanggal 12 Juli 2014. Tersedia: http://staff.uny.ac.id/sites/default/files/1
31655274/DISERTASI-DR-PUTUPUTU SUDIRA-UNY-2011.pdf

Suparman, A.(1997). Program pengembangan keterampilan dasar teknik instruksional (pekerti) untuk dosen muda. Jakarta. Universitas Terbuka

Sutrisno, E. (2009). Manajemen Sumber Daya Manusia. Jakarta: Kencana Prenada Media Group

Singh, M. (2009). Social and cultural aspects of informal sector learning: meeting the goals of EFA. In R. Maclean, D. Wilson, \& C. Chinien (Eds.), International handbook of education for the changing world of work, bridging academic and vocational learning (pp. 349-358). Bonn: Springer.

UNESCO-UNEVOC. (2001). Technical and vocational education and training (TVET). Diambil pada tanggal 27 Juni 2015, dari http://www.unevoc.unesco. org/go.php?q=TVETipedia+Glossary+ A-Z\&term=Technical+and+vocational+ education+and+training

Djojonegoro, W. (1998). Pengembangan sumber daya manusia melalui sekolah menengah kejuruan (SMK). Jakarta: PT Balai Pustaka.

Wonacott, M.E. (2003). A compilation history nad evaluation of vocational and carrer-technical education. Washington DC: Office of Education And Research Development. 